\title{
Peran Pondok Pesantren dalam Mencegah Faham Radikalisme di Pondok Pesantren Al-Ma'ruf Lamongan
}

Siti Suwaibatul Aslamiyah

Universitas Islam Lamongan

Suwaiba.0105@gmail.com

\section{Article History:}

Received : 06-09-2020

Revised : 09-09-2020

Accepted : 25-09-2020

\begin{abstract}
This research entitled The Role of Islamic Boarding Schools in Preventing Radicalism in the Al-Ma'ruf Lamongan Islamic Boarding School, in this study there are several things that will be examined, namely 1) the role of teaching in the Al-ma'ruf Islamic boarding school in preventing radicalism? 2) the role of kiai in the Al-ma'ruf Islamic boarding school in preventing radicalism? The researcher used qualitative methods and a case study approach. The results of the research of the subjects studied were first through the role of teaching books to understand religion, then the inculcation of disciplinary values, methods and aspects of the curriculum used in the Alma'ruf Islamic boarding school based on books or books that teach the values of understanding. moderate Islam, and the cultivation of the ideology of Ahlussunnah Wal jama'ah Annahdliyah (NU), the two roles of the kiai as role models, the kiai as advisors, and the Kiai as guides, hereby researchers want to know about the Role of Islamic Boarding Schools in Preventing Radicalism in Islamic Boarding Schools Al -Ma'ruf Kranggan Sidokumpul Lamongan.
\end{abstract}

Keyword: boarding school, radikalism, religious leader

\section{Pendahuluan}

Masalah Radikalisme kian hari semakin bertambah rumit dan selalu ramai menjadi perbincangan masyarakat, baik di televisi maupun di media sosial. Kita tahu rentetan kasus radikalisme yang menimpa Negara kita Indonesia sangatlah banyak, bentuk ancamanya semakin nyata, seperti penusukan kepada mantan menkopolhukam bapak Wiranto dan kasus kasus pengeboman dengan alasan dalih agama tentunya sangatlah miris. Seperti kasus ledakan bom di Surabaya yang melibatkan anak-anak tentu sangat memprihatinkan, Kapolri Jenderal Tito Karnavian mengatakan, saat ini ada fenomena bom bunuh diri menggunakan anak-anak dan perempuan. Menurut dia, fenomena menggunakan anak-anak untuk melakukan bom bunuh diri baru pertama kalinya di Indonesia. Namun, hal itu sudah beberapa kali dilakukan oleh isis. "di siria dan isis, mereka sudah lakukan. Sudah beberapa kali mereka menggunakan anak-anak."1

1Tito, "Bom Bunuh Diri Bawa Anak, Pertama Di Indonesia", dalam https://regional.kompas.com/read/2018/05/14/13025931/kapolri-bom-bunuh-diri-bawa-anakpertama-di-indonesia., diakses 19 November 2019. 
Kejadian seperti itu tentu tidak jauh dari latar belakang pemahaman agama yang dangkal, bagaimana mungkin seorang ayah yang tega mengajak anaknya untuk bunuh diri dengan meledakkan bom di tubuhnya, apapun alasannya tentu tidak dibenarkan oleh agama manapun, faham radikalisme semacam itu bukan hanya membahayakan dirinya sendiri, namun orang lain yang menjadi sasaran, bahkan keluarganya sendiri. Radikalisme dapat dikatakan suatu faham atau cara fikir yang menjadi landasan untuk melakukan gerakan kriminal atau teror, Dalam dunia pendidikan tidak bisa terhindar dari fenomena fenomena kekerasan yang menjadikan tujuan pendidikan gagal diraih. Radikalisme bisa muncul dari berbagai elemen dalam pendidikan. Secara umum fenomena radikalisme dalam pendidikan lahir dari guru kepada siswa, dari siswa kepada guru dan juga dari orang tua atau masyarakat kepada elemen-elemen yang ada di dalam pendidikan.Wakil Presiden Ma'ruf Amin menyatakan, "Radikalisme harus ditangani sejak dini. Karenanya, menangani terorisme tidak bisa dilakukan oleh satu kementerian atau lembaga, tetapi oleh banyak pihak dan secara komprehensif. "Penanganannya dilakukan secara komprehensif dari hulu sampe ke hilir". ${ }^{2}$

Pesantren mempunyai peran penting dalam membentengi dari faham radikalisme karena pondok pesantren mengajarkan Cara berpikir dan berkepribadian tawazun, moderat serta mengedepankan kebenaran universal. ${ }^{3}$

Pondok Pesantren sebagai lembaga pendidikan yang mempunyai tujuan yang tidak jauh berbeda dengan pendidikan agama Islam yakni mencapai akhlak yang sempurna atau mendidik budi pekerti dan jiwa. Maksud mencapai akhlak yang sempurna yakni dapat digambarkan pada terciptanya pribadi muslim yang mempunyai indikator iman, taqwa>, ta'at dalam menjalankan ibadah, berakhlak mulia dan dewasa secara jasmani dan rohani, serta berusaha untuk hidup sesuai dengan ajaran Islam. Melihat kiprah pesantren dalam kegiatan dakwah dikalangan masyarakat, dalam arti kata melakukan suatu aktifitas menumbuhkan kesadaran beragama atau melaksanakan ajaran-ajaran agama secara konsekuen sebagai pemeluk agama Islam. ${ }^{4}$

Sebagaimana kita ketahui bahwa semenjak berdirinya pesantren merupakan pusat penyebaran agama Islam baik dalam masalah aqidah, atau syari'ah di Indonesia. Fungsi pesantren sebagai penyiaran agama terlihat dari elemen pondok pesantren itu sendiri yakni masjid pesantren, yang dalam operasionalnya juga berfungsi sebagai masjid umum, yaitu sebagai tempat belajar agama dan ibadah masyarakat umum. Masjid pesantren sering dipakai masyarakat umum untuk menyelenggarakan majelis $t a ' l i>m$ (pengajian) diskusi-diskusi keagamaan dan lain sebagainya. ${ }^{5}$

Di pesantren juga menjunjung Sikap Tasamuh yakni merupakan salah satu potensi yang dimiliki oleh pondok pesantren dikarenakan, Pesantren merupakan sebuah miniatur masyarakat yang terdiri dari berbagai suku-suku, adat istiadat dan budaya

2Ma'ruf Amin, "Radikalisme Perlu Ditangani Sejak Usia Dini Hulu Ke Hilir", dalam https://nasional.kompas.com/read/2019/11/15/20013231/wapres-sebut-radikalisme-perlu-ditanganisejak-usia-dini-hulu-ke-hilir., diakses Pada 18 November 2019.

${ }^{3}$ M. Saekan Muchith, "Radikalisme Dalam Dunia Pendidikan", Jurnal Akademik, Vol. 10, , No. 1 (Februari 2016), 179

${ }^{4}$ M.Bahri Ghazali, Pesantren Berwawasan Lingkungan (Jakarta: Prasasti, 2003), 38.

${ }^{5}$ Mastuhu, Dinamika Sistem Pendidikan Pesantren (Jakarta: Inis, 1994), 61. 
yang mereka semua berkumpul dalam sebuah pesantren, santri-santrinya tidak hanya berasal dari daerah tertentu saja, melainkan berasal dari berbagai daerah bahkan ada pula dari berbagai bangsa. Kondisi kehidupan yang seperti inilah yang menuntut para santri agar memiliki kemampuan bertoleransi yang baik dengan orang yang memiliki kultur dan karakteristik yang berbeda-beda. Kemampuan inilah yang akan menjadi modal penting bagi para santri ketika terjun ke dalam lingkungan masyarakat untuk memastikan terciptanya kehidupan yang damai dan rukun. ${ }^{6}$

Dewasa ini pesantren mempunyai peran ganda yakni di samping sebagai menjaga moral juga menjadi pewaris khazanah islam klasik melalui penguasaan terhadap "kitab kuning" melalui kedalaman penguasaan ilmu keagamaan dan ditunjang dengan pelaksaan ritual keagamaan yang ketat menjadikan kaum santri memiliki kedalaman spiritual yang kuat.oleh karenanya menjadikan mereka pengayom masyarakat, khususnya memebentengi berbagai bentuk prilaku moral sebagai dampak arus globalisasi.

Begitu juga di pondok pesantren Al-ma'ruf,7 meski disana tidak ditemukan kasus santri yang bergabung dengan kelompok-kelompok gerakan radikal, hanya saja ketika keluar atau sudah lepas dari pesantren ada beberapa yang bergabung dengan kelompokkelompok seperti organisasi hisbut tahrir, sehingga pondok pesantren Al-ma'ruf mengantisipasi adanya kasus seperti yang disebutkan diatas melalui penanaman nilainailai ideologi ahlusunnah wal jamaah dan penguatan pendidikan karakter dan pengajaran. Dengan demikian, pendidikan pesantren sangatlah berperan penting dalam mencegaha faham radikalisme.

Penelitian ini menggunakan jenis penelitian kualitatif, hal ini dikarenakan akan lebih memusatkan pada keingin-tahuan tentang strategi pondok pesantren dalam mencegah faham radikalisme agama. Adapun pendekatan yang digunakan adalah pendekatan fenomenologis, yaitu pendekatan yang berpendapat bahwa kebenaran sesuatu diperoleh dengan cara menangkap fenomena dari objek yang diteliti. Dalam pengumpulan data di lapangan dalam sebuah penelitian tentu banyak cara yang dapat digunakan agar masing-masing metode tersebut dapat saling melengkapi dan menyempurnakan, maka dalam pengumpulan data penelitian ini peneliti menggunakan metode observasi, wawancara, dan dokumentasi.

Dalam kegiatan observasi peneliti bisa membawa check list, rating scale, atau catatan berkala sebagai instrumen observasi. Sehingga dalam kegiatan observasi ada pencatatan melalui chek list yang telah disusun peneliti. Pengamatan dapat dilakukan dalam situasi dan objek asli (alamiah) atau pada objek buatan (by design). Dilihat dari cara melakukannya, ada dua macam observasi, yaitu observasi langsung dan observasi tidak langsung. Observasi langsung adalah kegiatan pengamatan yang dilakukan oleh peneliti dalam kancah atau objek penelitian secara langsung. Peneliti bisa melakukan interaksi visual dengan objek yang diteliti. Sedangkan observasi tidak langsung adalah pengamatan yang dilakukan peneliti dengan menggunakan alat bantu, baik elektronik

6 Syamsul Ma'arif, Pesantren Inklusif Berbasis Kearifan Lokal (Yogyakarta: Kaukaba Dipantara, 2015) hlm 208-209.

${ }^{7}$ Pondok pesantren Al-ma'ruf, observasi, 3 November 2019. 
maupun manusia. Secara teknis, peneliti dapat menggunakan alat bantu perekam gambar untuk melakukan observasi tidak langsung.

Teknik observasi ini menjadi teknik pengumpulan data utama untuk penelitian yang target datanya berupa tingkah laku atau interaksi. Teknik observasi dibagi menjadi dua, yaitu observasi terbuka dan observasi tertutup. Observasi terbuka adalah pengamatan yang dilakukan peneliti dan diketahui oleh orang yang diamati. Model observasi seperti ini disebut juga observasi partisipatif, peneliti melakukan interaksi dengan orang yang diteliti. Sedangkan observasi tertutup adalah pengamatan yang dilakukan peneliti dimana orang yang diteliti tahu kalau sedang diobservasi. Peneliti menjaga jarak dan tidak melakukan interaksi dengan yang diamati.

Pada teknik wawancara peneliti mengumpulkan data dengan mengajukan pertanyaan secara langsung kepada informan dan jawaban-jawaban informan dicatat atau direkam dengan alat perekam. Wawancara juga bisa dikatakan sebagai proses komunikasi atau interaksi untuk mengumpulkan informasi dengan cara tanya jawab antara peneliti dengan informan atau subjek penelitian. Dengan kemajuan teknologi informasi seperti saat ini, wawancara bisa saja dilakukan tanpa tatap muka, yakni melalui media telekomunikasi. Pada hakikatnya wawancara merupakan kegiatan untuk memperoleh informasi secara mendalam tentang sebuah isu atau tema yang diangkat dalam penelitian. Atau, merupakan proses pembuktian terhadap informasi atau keterangan yang telah diperoleh lewat teknik yang lain sebelumnya.

Teknik dokumentasi sengaja digunakan dalam penelitian ini, sebab: Pertama, sumber ini selalu tersedia dan murah terutama ditinjau dari waktu; Kedua, merupakan sumber informasi yang stabil, baik keakuratannya dalam merefleksikan situasi yang terjadi dimasa lampau, maupun dapat dan dianalisis kembali tanpa mengalami perubahan; Ketiga, rekaman dan dokumen merupakan sumber informasi yang kaya, secara kontekstual relevan dan mendasar dalam konteksnya; Keempat, sumber ini sering merupakan pernyataan legal yang dapat memenuhi akuntabilitas. Hasil pengumpulan data melalui cara dokumentasi ini, dicatat dalam format rekaman dokumentasi. Dalam hal ini penulis berusaha menggali data melalui dokumen, baik berupa catatan harian, dokumentasi hasil wawancara, gambar dan lain-lain.

Setelah semua data terkumpul, maka data tersebut perlu untuk di analisis. Analisis yang dilakukan berupa mengidentifikasi data, menyeleksi, dan selanjutnya dilakukan klasifikasi data, serta menyusun data. Diharapkan dari pengelolaan data tersebut dapat diperoleh gambaran yang akurat dan konkrit dari subjek penelitian.

\section{Akar Teologis dan Politis Fundamentalisme Islam}

Untuk memahami kemunculan fundamentalisme islam, secara teoritik dapat dikategorikan menjadi dua periode, yaitu pra-modern dan kontemporer ${ }^{8}$. Dengan melakukan analisa melalui perspektif sejarah ini, fenomena fundamentalisme islam sebenarnya tidaklah sepenuhnya baru. Sebelum munculnya fundamentalisme 
kontemporer, jauh sebelum itu fundamentalisme Islam telah menampakkan gelagatnya akibat gesekan-gesekan sosiologis di tubuh islam sendiri pada waktu itu. Fenomena ini berbeda dengan fundamentalisme kontemporer yang lebih diakibatkan sebagai reaksi atas penetrasi sistem yang komplek, baik dari segi ekonomi, politik, budaya dan nilai sosial dari Barat ${ }^{9}$. Baik melalui kontak langsung dengan Barat (baca: peperangan), maupun melalui pemikiran para sarjana Muslim.

Akibat dari benturan ini, pemikiran islam yang semula merupakan kepercayaan yang open-minded, inklusif dan toleran, dewasa ini mengalami pergeseran yang cukup serius kearah desesif, yakni dari arah teologikal-tradisional pada lapangan sosiologis yang menformulasikan islam, ke dalam norma-norma dan nilai-nilai pada tatanan sosiopolitik. Sehingga karena sifatnya yang ideologis, islam selanjutnya dipahami sebagai kepercayaan tentang legitimasi yang terdiri dari intrerpretasi-interpretasi teks-teks keagamaan untuk dimanfaatkan dalam ranah yang sangat kuratif dalam bidang sosialpolitik. ${ }^{10}$

Jika dirunut kebelakang, maka islam jenis ini mulai menampakkan gelagatnya secara jelas ketika terjadi perseteruan dahsyat antara Khalifah Ali ibn Abi T\}alib dengan pihak Muawiy>ah ibn Abi Sufyan dengan tahkim sebagai pemicunya. Kesepakatan antara pihak Ali yang diwakili oleh Abu Musa Al-Ash'ari dan disisi lain Amr bin As\}h yang mewakili pihak Muawiyah menghasilkan kesepakatan yang pada akhirnya melahirkan kelompok penentang hasil kesepakatan "manusia" tersebut. Wal hasil, kelompok yang tidak setuju dengan perjanjian antara pihak Ali dan Muawiyah tersebut menganggap kafir semua yang terlibat dalam peristiwa tahkim, sehingga halal darahnya untuk dibunuh. ${ }^{11}$

Sesungguhnya, aliran fundamentalisme islam yang belakangan disebut kelompok khawarij inilah yang bertanggung jawab menyeret konflik politik-kekhalifahan ke wilayah paling suci yang bernama "agama" dengan menegaskan slogan "laa hukmu illallah" dan "wa man lam yahkkum bima anzalallahu faulaika humu al-kafirun" sebagai prinsip yang tak bisa tergantikan oleh berbagai macam product manusia. Kaum fundamentalisme dalam bahasa arab mengidentifikasikan dirinya dengan berbagai macam istilah, yang antara lain; usuliyah al-islamiyah (dasar-dasar agama), al-syahwah al-isla>miyah (kebangunan islam) atau juga al-ab'as al-islami (kebangkitan islam). Terdapat juga istilah yang berasal dari mereka, namun mengandung perspeksi yang agak sinis. Mereka menyebutnya dengan istilah al-muta'asibun (orang-orang fanatik) ataupun mutat\}arrifun (orang-orang radikal). ${ }^{12}$

Sudah ditengarai diatas, bahwa kemunculan islam fundamentalis dalam ranah sejarahnya berawal dari persolan politik, sehingga pola gerakannya sampai sekarang yakni mencita-citakan sebuah tatanan masyarakat (political will) yang ideal dengan

${ }^{9}$ Agus Maftuh Abegebriel,dkk, Negara Tuhan, (Yogjakarta: SR-Ins Publishing, 2004), 508

10 Ibid,. 495.

${ }^{11}$ Cerita lengkap mengenai perseteruan antara Ali Ibn Abi Talib dan Muawiyah ini bisa dibaca lebih jelas dalam, Ali Auda, Ali bin Abi Talib, (Jakarta: Litera AntarNusa, 2008, cet IV), 276; dan Siradjudin Abbas, I't\}iqad Ahlusunnah wa al-jama'ah, (Jakarta: Pustaka Tarbiyah, 2004), 167.

12 Muhammad Abid Al-Jabiri dan Hasan Hanafi, Hiwar al-Mashriq wa al-Magrib, (Beirut: alMuassasah al-'Arabiyah,1990), 23-28. 
berlandaskan pada fundamennya secara langsung, yaitu Al-Quran dan Al-Hadits. Penekanan masalah ini, telah berhasil melahirkan konsepsi yang disebut sebagai alnizam al-islami sebagai sistem islam dalam urusan ketatanegaraan.

Cita-cita politik diatas, merupakan sebuah kewajiban bagi mereka untuk mengimplementasikannya pada setiap kaum muslimin serta harus dilakukan secara langsung, tidak bertahap. Esensi al-nizam al-islami diatas, tidak lain merupakan ideologi alternatif yang diperjuangkan kelopok islam politik, yang memandang bahwa sistem poltik sekuler (siyasah al-dunya) telah terbukti gagal mengangkat derajat kaum muslimin. Sebagai bentuk rapprochement antara politik dan agama (syari'ah), al-nizam al-islami diyakini sebagai satu-satunya alternatif untuk menangkis penetrasi intelektual Barat. 13

\section{Karakteristik Islam Fundamentalis: Sebuah Tabiat Gerakan Radikal}

Secara umum, fundamentalisme bisa dimaknai sebagai paham untuk kembali kepada sesuatu yang dipandang sebagai dasar atau pokok ajaran yang nilainya "pasti benar" atau "tidak mungkin salah". Hal ini meniscayakan untuk merujuk pada sumber hukum primer yakni Al-Quran dan Al-Hadis sebagai teks suci yang tidak boleh diotakatik kesakralannya. Upaya untuk mempertahankan "anggapan" kebenaran teks-teks tersebut dipahami sebagai upaya mempertahankan kemurnian dan kebenaran agama itu sendiri. Dengan keyakinan kuat semacam ini, maka pendukung kaum fundamentalis merasa perjuangannya bukan merupakan pekerjaan yang sia-sia belaka, karena perjuangan mereka sudah dilegitimasi dengan istilah yang mereka anggap sebagai jihad fii sabilillah. ${ }^{14}$

Fundamentalisme dalam perjalanan sejarahnya sudah banyak mengalami pergeseran makna, yang tak lagi sekedar kategori sosiologis pemeluk (islam), namun secara ironi sangat kental muatan ideologis yang menyiratkan cemoohan, cacian dan ejekan (dan pembunuhan) kepada sesama umat islam. Sikap ekslusif semacam ini memang didasari pada pemahaman yang menilai bahwa siapa saja yang tidak sama dengannya merupakan pihak yang mendapat predikat kafir, syirik dan halal darahnya untuk dibunuh.

Disisi lain, kemunculan fundamentalisme Islam pernah dikuak dalam tesisnya Samuel P. Huntington mengenai The Clash of Civilization antara islam dan Barat, hanya merupakan konspirasi dan akal-akalan -terutama pihak Amerika dan Eropa- akan kekhawatirannya terhadap perkembangan dan kemajuan islam seperti dulu. Sehingga, dengan berbagai macam konspirasi tingkat tinggi, maka negara-negara pemegang kepentingan ini merasa perlu menciptakan stigma masyarakat terhadap islam agar dilihat sebagai suatu agama yang picik, militan, teroris dan cenderung membuat kerusakan dan ketidak nyamanan.

Realitas seperti inilah yang pada sejarah perkembangannya dikenal dengan fundamentalisme kontemporer. Yakni, keislaman yang lebih bersikap reaktif terhadap

13 Bassam Tibi, Islam and The Culural Acomodation of Social Change, (California: University of Caliifornia, 1991), 32

${ }^{14}$ Rumadi, Renungan Santri, (Jakarta: Erlangga, 2002), 26. 
permasalahn politik-kenegaraan sebagai langkah mengconter tekanan bangsa Barat ketimbang upaya penajaman aspek spiritual-religius yang membawa pada perbaikan moral. Selain memiliki agenda politisasi islam, kaum fundamentalisme dapat disinyalir menjadi ancaman bagi tatanan dunia. Sebagai bentuk dari reaksi krisis politik, ekonomi dan budaya yang menimpa negeri-negeri muslim. Fundamentalisme ditengarai menawarkan solusi terhadap bentuk ideologi alternative (islam) sebagai problem solver. "Islam" sebagaimana yang diyakini mereka merupakan jalan damai menuju terbentuknya Negara Islam, suatu imaginasi politik yang diciptakan kaum fundamentalis untuk meraih cita-citanya membangun sistem sosio-politik (negara) berdasarkan syari'at islam.

Bassam Tibi melukiskan dua point utama dalam tubuh fundamentalisme. Pertama, fundamentalisme agama -sebagai sebuah fenomena politik yang tidak terbatas didunia islam- adalah politisasi agama yang agresif yang dilakukan demi mencapai tujuan-tujuan agama. Kedua, fundamentalisme islam atau yang lain, hanyalah bentuk superfisial dari terorisme atau ekstrimisme. ${ }^{15}$

Dalam pola gerakannya, Marty mensinyalir terjadi kesamaan pola pergerakan Islam fundamentalisme ini. Marty menyebut empat hal pokok sebagai identifikasi jenis islam garis keras ini.

Pertama, memiliki prinsip yang mengarah pada paham perlawanan (oppotionalisme). Agama yang hadir dimuka bumi ini dipastikan memiliki kekuatan yang berupaya membebaskan manusia dari segala belenggu ketertindasan. Bahkan, pola gerakan yang mengatasnamakan agama seringkali bersikap radikal hanya dengan alasan memperjuangkan secara "murni" agamanya, serta memngambil jarak dengan modernism. Acuan dan tolak ukur untuk bisa melakuakn perubahan baik dari tatana sosial sampai politik, secara total diserahkan pada teks-teks Al-Quran dan Hadis.

Kedua, penolakan terhadap hermeneutika. Kontekstualisasi al-Quran yang berawal dari teks-teks yang bersifat normative menurut kalangan fundamentalisme islam, merupakan sebuah hal yang tidak diperkenankan. Teks Al-Quran tidak hanya dipahami secara literal, akan tetapi manusia diyakini tidak mempunyai kewenangan dalam interpretasi al-Qur'an.

Ketiga, secara epistimologis, fundamentalisme islam dalam wilayah gerakan sosiail politikmenolak pluralism dan relativisme. Mereka menganggap bahwa kedua hal ini merupakan tafsiran yang keliru dari manusia dalam memaknai al-Quran secara benar.

Keempat, penolakan terhadap perkembangan historis dan sosiologis. Menurut mereka, ummat manusia yang tengah melakukan aktivisme sejarah di dunia harus menyesuaikan teks-teks al-Quran. ${ }^{16}$

Dalam konteks kekinian, ada beberapa kelompok yang secara tegas mempunyai cita-cita suci, yakni khilafah Establishing (pembangunan kembali khilafah global) yang

15 Bassam Tibi, The Challenge of Fundamntalism: Political Islam and the New World Disorder, (California: University of California, 1998), 2.

16 Martin E. Marty, "What is Fundamentalism? Theological Perspektive”, dalam Kung \& Moltman (ed), Fundamentalism as a Ecumenical Challenge, (London: 1993), 57. 
direprentasikan secara massive oleh Hizbut Tahrir (HT) dan Jama'ah Islamiyah (JI). Yang disebut diakhir, bahkan sudah menjadi gerakan yang mempunyai konsep sangat rapi dalam merealisasikan impiannya. Menurut hasil penelitian yang dilakukan oleh Agus Maftuh, gerakan ini sudah mencapai bentuk organisasi gerakan yang bersifat 'alamy atau international yang tidak dibatasi oleh wilayah teritorial Negara. Mereka sudah mempunyai semaca, "pedoman suci" yang bertitel PUPJI (Pedoman Umum Perjuangan Al-Jama'ah al-Islamiyah) yang memuat tujuan, target dan strategi untuk proyek pendirian kekhalifahan. ${ }^{17}$

Anggapan akan kesucian perjuangan mereka yang melegitimasikan dirinya sebagai pelaku jihad, dalam proses perkembangan sejarahnya malah mendapatkan angin segar dengan hadirnya sebuah kitab karya Abdu as-Salam Faraj yang berjudul alfaridah al-ghaibah. Yang dimaksud dengan al-faridah al-ghaibah adalah jihad, yaitu perang suci yang diumumkan untuk menentang penguasa yang tiran dan dzolim ${ }^{18}$. Pada perkembangan selanjutnya, gerakan jihad ini malah menjadi gerakan yang bermuatan ideologis. Secara singkat dijelaskan bahwa manuskrip Faraj ini memulai bahasannya dengan memaparkan hal berikut:

"Sesungguhnya jihad di jalan Allah, sungguhpun sangat penting dan mendesak untuk masa depan Agama ini, tetapi banyak ulama modern yang melecehkannya dan mengingkarinya, padahal mereka tahu bahwa jihad satu-satunya jalan untuk mengembalikan dan mengangkat suara Islam pada masa kini, semoga Allah menanamkan kepada setiap muslim dengan pemikiran dan falsafah yang ditetapkan Allah SWT untuk kemuliaan hamba-Nya". ${ }^{19}$

Mereka beranggapan bahwa, kebrobokan yang mencengkram dunia Islam saat ini tidak bisa dirubah kecuali hanya dengan kekuatan pedang (atau senjata rakitan pada masa kini). Keyakinan semacam ini sangat masuk akal ketika dibenturkan dengan hadits Nabi yang "seakan" melegitimasi perjuangan kelompok garis keras ini, Rasulullah pernah menyampaikan statementnya dalam sebuah kesempatan. " saya diutus dengan pedang setiap saat, sampai manusia hanya menyembah Allah yang tidak ada sekutu bagi-Nya,".

Pernyataan Rasul diatas semakin meneguhkan keyakinan mereka akan pentingnya membuat tatanan masyarakat yang selalu melakukan segala aktifitasnya berlandaskan Al-Quran dan Hadits. Kenyataan ini, juga diperkuat dengan dalil al-Quran yang mengandung makna bahwa siapa saja yang memberlakukan hukum (baik dalam

17 Bahkan kelompok ini menjadikan NKRI sebagai qa'idah amina (safe area) atau base camp menuju terbentuknya Khilafah islamiyah ala Minhajin Nubuwah. Tidak hanya itu, JI juga telah mempunyai Nidl\}om Asasi atau semacam UUD yang mengatur mekanisme gerakan, dan yang lebih mengagetkan lagi, mereka juga sudah menyiapkan semacam Military Training dengan empat materi pokok; Weapon Training, Teknik Infanteri, Map reading dan Field Engineering lengkap dengan bombing trainingnya. Baca Selengkapnya dalam Agus Maftuh, Negara Tuhan, 2008, xi.

18 Kudeta dan sikap pemboikotan terhadap pemerintah resmi dalam sejarah kekinian, mencapai puncaknya ketika kelompok ekstrimis ini berhasil menembak mati Presiden Mesir Anwar Sadat ketika sedang berlangung perayaan untuk memperingati kemenangan Mesir atas Israel. Baca selengkapnya dalam Ali Syu'aibi \& Gills Kibil, Meluruskan Radikalisme Islam, terj: Muhtarom (Yogjakarta: Duta AKsara Mulia, 2010), 107.

19 Ibid, 109. 
bidang ekonomi, sosial dan budaya) tidak seperti yang Allah perintahkan, maka sama halnya ia melakukan kekafiran.

"Barangsiapa yang tidak memutuskan menurut apa yang diturunkan Allah, Maka mereka itu adalah orang-orang yang kafir" (QS: Al-Ma'idah: 44).

Legitimasi kedua sumber hukum islam utama inilah (shari'ah) yang seakan "mendukung" kebringasan pola pikir dan amalan-amalan para ektremis untuk memperjuangkan islam yang mereka anggap suci. Konsep pemaknaan jihad seperti ini, menurut Sayyid Qutb merupakan perjuangan politik revolusioner yang sengaja dikonsepsikan ajaran islam untuk melucuti musuh-musuh islam (baca: hegemoni Barat). Abu al-a'la Al-Maududi (w.1979 M) lebih radikal lagi dengan menyejajarkan "gerakan politik revolusioner" ini sebanding dengan ideologi dan gerakan revolusioner lain seperti Marxisme, Nazisme dan Fasisme. ${ }^{20}$

Dari pemaparan inilah jelas terlihat bahwa perjuangan islam fundamentalis merupakan hasil dari berbagai macam pengalaman historis yang dibarengi dengan pemaknaan teks-teks keagamaan untuk melakukan perlawanan atas penekanan yang dialami umat islam. Stigma the other yang dipredikatkan kepada kelompok yang dianggap tidak sama dengannya meniscayakan adanya sikap kuratif kelompok ini, sehingga klaim pengkafiran dan pemusyrikan tidak segan-segan keluar dari mulut mereka yang -seiring dengan itu- mereka anggap berlandaskan Al-Quran dan Hadits.

\section{Peran Pengajaran di Pondok Pesantren Al-Ma'ruf dalam Mencegah Faham Radikalisme}

Berdasarkan Undang-Undang Nomor 20 tahun 2003 tentang Sistem Pendidikan Nasional, Pasal 3, tujuan pendidikan nasional adalah Mengembangkan potensi peserta didik agar menjadi manusia yang beriman dan bertakwa kepada Tuhan Yang Maha Esa, berakhlak mulia, sehat, berilmu, cakap, kreatif, mandiri, dan menjadi warga negara yang demokratis serta bertanggung jawab. ${ }^{21}$ Profesor Mastuhu menjelaskan bahwa tujuan utama pesantren adalah untuk mencapai hikmah atau wisdom (kebijaksanaan) berdasarkan pada ajaran Islam yang dimaksudkan untuk meningkatkan pemahaman tentang arti kehidupan serta realisasi dari peran-peran dan tanggung jawab sosial 22

Berdasarkan Undang-Undang dan teori di atas memiliki persamaan dan tujuan yang ada di pondok pesantren Al-ma'ruf terkhusus dalam membentuk generasi yang memahami kebijaksanaan dalam beragama islam, serta merealisasikan dari peranperan dan tanggung jawab sosial .

Pengajaran di Pondok Al- ma'ruf yang di tekankan adalah ilmu aqidah kitab Aqidah Islamiyah ini membahas aqidah yang diajaran rasulullah dan dikemas rapih dalam manhaj Abu Hasan al-Asy'ari dan imam Abu Mansur Al-maturidi, sehingga santri memiliki aqidah yang kuat dan tidak mudah terpapar faham yang mengajarkan kekerasan dan mampu membentuk manusia yang beriman serta bertaqwa, selain itu

${ }^{20}$ Rumadi, Renungan Santri: Dari Jihad Hingga Kritik wacana Agama, (Jakarta: Erlangga, 2010), 79.

21 Undang-Undang Nomor 20 tahun 2003 tentang Sistem Pendidikan Nasional,

22 M. Dian Nafi', Dkk, Praksis Pembelajaran Pesantren (Yogyakarta: Instite For Training And Development (Itd) Amherst, 2007), 49. 
pondok pesantren Al-ma'ruf dalam menafsirkan ayat-ayat Al-qur'an memakai kitab tafsir jalalain sehingga dalam memahaminya akan jauh dari sikap ekstrim, Pesantren ini sangat menanamkan kedisiplinan, selain metode sorogan wetonan, juga di terapkan metode Tanya jawab, demonstrasi atau praktek, juga pemberian tugas, para santri juga diperbolehkan bertanya, yang kadang berbeda pandangan dengan ustadz, selanjutnya aspek kurikulum yang digunakan di pondok pesantren Al-ma'ruf berpedoman pada kitab atau buku yang mengajarkan nilai-nilai paham islam yang moderat, dan tidak mengajarkan kekerasan. ideologi yang di tanamkan kepada peserta didik adalah ahlussunnah waljamaah anahdliyah (NU), yakni dicirikan dengan empat.

Pertama, tawasuth (moderat). Doktrin ini mengajarkan bahwa manusia memiliki kebebasan untuk melaksanakan suatu aktivitas tetapi sebebas apapun manusia masih dibatasi oleh kehendak Tuhan Yang Maha Kuasa. Artinya dapam meraih kesuksesan, manusia wajib ihtiyar secara optimal tetapi jangan lupa bahwa Allah swt juga ikut menentukan keberhasilan. Setelah berusaha manusia wajib berdoa dan pasrah kepada Allah swt. Kedua, tawazun ( keseimbangan). Doktrin ini mengajarkan bahwa manusia dalam memandang suatu realitas tidak boleh bersifat ektrem baik kekiri atupun ke kanan. Artinya manusia yang bauk tidak terlalu berlebihan pada saat senang atau benci kepada sesuatu. Hal ini didasarkan asumsi bahwa sebaik baik menurut pandangan manusia belum tentu baik menurut Allah swt, sebaliknya sejelek jelek dalam pandangan manusia juga belum tentu jelek menurut Allah swt. Ketiga, i'tidal (keadilan). Doktrin ini mengajarkan bahwa diantara sesama manusia harus saling memberikan kepercayaan dan kepercayaan yang dibangun harus memberikan peran secara proporsional. Dunia akan cepat hancur jika masing masing elemen tidak memiliki kesadaran untuk melaksanakan peran masing masing secara proporsional. Keempat, tatharruf (universalisme). Doktrin ini mengajarkan Setiap manusia agar lebih mengedepankan pemahaman islam yang bersifat universal (global). Kebenaran Islam dilihat dari norma norma yang bersifat umum seperti keadilan, kemanusiaan, keselamatan dan kesejahteraan.

\section{Peran kiai di Pondok Pesantren Al-Ma'ruf dalam mencegah faham radikalisme}

\section{Kiai sebagai suri tauladan}

Pada dasarnya di dalam lembaga pendidikan pondok pesantren, seorang kiai bertanggung jawab atas segala yang bersangkutan dengan santrinya dan bertanggung jawab terhadap seluruh aspek jalanya kegiatan di pesantren. Seorang kiai hendaknya senantiasa berprilaku baik agar di tiru murid-muridnya. Lazimnya seorang anak yang meniru apa-apa yang di kerjakan oleh anaknya. Sebagai suri tauladan seorang kiai diharapkan mampu menanamkan prilaku religious kepada santrinya agar terbentuk ahlakul karimah, sehingga budaya prilaku religious menjadi kebiasaan baik yang diamalkan dalam kehidupan sehari-hari.

\section{Kiai sebagai penasehat}

Sebagai seorang pimpinan peran kiai dalam menasehati seluruh elemen di pondok pesantren sangatlah dibutuhkan, Seorang kiai memiliki jalinan ikatan batin atau 
emosional dengan parasantri-santrinya. Dalam hubungan ini kiai berperan aktif sebagai penasehat. Baik diminta ataupun tidak. Oleh karena itu hubungan batin dan emosional antara kiai dan santri dapat terjalin efektif, bila sasaran utamanya adalah menyampaikan nilai-nilai moral, maka peranan kiai dalam menyampaikan nasehat menjadi sesuatu yang pokok, sehingga santri-santri akan merasa diayomi. Pendidikan agama Islam berusaha melahirkan generasi yang beriman, berilmu, dan beramal saleh. Sehingga dalam suatu pendidikan moral, harus didasari oleh adanya semangat moral yang tinggi dan akhlak yang baik. Untuk itu seorang kiai disini sebagai pengemban amanah haruslah orang yang memiliki pribadi baik.

\section{Kiai sebagai pembimbing}

Peran kiai sebagai pembimbing sangat berkaitan erat dengan praktik keseharian. Untuk dapat menjadi seorang pembimbing, seorang kiai harus mampu memperlakukan para santri dengan menghormati dan menyayanginya. Kiai sebenarnya sama dengan perlakuan orang tua terhadap anak-anaknya yaitu penuh respek, kasih sayang serta memberikan perlindungan. Sehingga, siswa merasa senang dan familiar untuk samasama menerima pelajaran dari pendidiknya tanpa ada paksaan, tekanan dan sejenisnya. Pada intinya, setiap siswa dapat merasa percaya diri bahwa di lingkungan pesantren, ia akan sukses belajar lantaran ia merasa dibimbing, didorong, dan diarahkan. Bahkan, dalam hal-hal tertentu kiai harus membimbing dan mengarahkan satu persatdari seluruh santri yang ada.

\section{Kesimpulan}

Peran Pondok Pesantren sangat penting dalam mencegah faham radikalisme yang bertentangan dengan syariat agama Islam, maka perlu untuk disadari bahwa betapa pentingnya memberikan pemahaman agama Islam dengan jelas kepada para santri, sehingga santri tidak mudah untuk didoktrin oleh paham radikalisme agama. Melalui peran pengajaran di pondok pesantren Al-ma'ruf santri diajarkan pemahaman ideologi ahlussunnah waljamaah anahdliyah (NU), yakni dicirikan dengan tawasuth (moderat). tawazun ( keseimbangan). i'tidal (keadilan). Dan tatharruf (universalisme). Kemudian melalui peran kiai, pertama kiai sebagai suri tauladan, berprilaku baik agar di tiru murid-muridnya. Lazimnya seorang anak yang meniru apa-apa yang di kerjakan oleh anaknya. Kedua Kiai sebagai penasehat, Sebagai seorang pimpinan peran kiai dalam menasehati seluruh elemen di pondok pesantren sangatlah dibutuhkan, ketiga Kiai sebagai pembimbing Peran kiai sebagai pembimbing sangat berkaitan erat dengan praktik keseharian. Untuk dapat menjadi seorang pembimbing, seorang kiai harus mampu memperlakukan para santri dengan menghormati dan menyayanginya.

Itulah beberapa cara pondok pesantren Al-ma'ruf dalam mencegah faham radikalisme yang merupakan embrio dari sebuah tindakan kekerasan yang mempunyai akar dan jaringan Kompleks yang tidak hanya bisa didekati dengan pendekatan kelembagaan melalui Penegakan hukum semata. Namun juga dibutuhkan Keterlibatan masyarakat terutama lingkungan Lembaga pendidikan, keluarga dan lingkungan 
masyarakat serta generasi muda itu Sendiri. demi Keberlangsungan kehidupan bangsa dan negara tercinta yang damai.

\section{Daftar Rujukan}

Tito, "Bom Bunuh Diri Bawa Anak, Pertama Di Indonesia", dalam https://regional.kompas.com/read/2018/05/14/13025931/kapolri-bom-bunuhdiri-bawa-anak-pertama-di-indonesia., diakses 19 November 2019.

Ma'ruf Amin, "Radikalisme Perlu Ditangani Sejak Usia Dini Hulu Ke Hilir", dalam https://nasional.kompas.com/read/2019/11/15/20013231/wapres-sebutradikalisme-perlu-ditangani-sejak-usia-dini-hulu-ke-hilir., diakses Pada 18 November 2019.

M. Saekan Muchith, “Radikalisme Dalam Dunia Pendidikan”, Jurnal Akademik, Vol. 10, No. 1. Februari 2016.

M.Bahri Ghazali, Pesantren Berwawasan Lingkungan. Jakarta: Prasasti, 2003.

Mastuhu, Dinamika Sistem Pendidikan Pesantren. Jakarta: Inis, 1994.

Syamsul Ma'arif, Pesantren Inklusif Berbasis Kearifan Lokal. Yogyakarta: Kaukaba Dipantara. 2015.

Undang-Undang Nomor 20 tahun 2003 tentang Sistem Pendidikan Nasional.

M. Dian Nafi', Dkk, Praksis Pembelajaran Pesantren. Yogyakarta: Instite For Training And Development (Itd) Amherst, 2007.

Azumardi Azra, Pergolakan Politik Islam: dari Fundamentalisme, Modernisme dan postModernisme. Jakarta: Paramadina, 1996.

Agus Maftuh Abegebriel,dkk, Negara Tuhan. Yogjakarta: SR-Ins Publishing, 2004.

Ali Auda, Ali bin Abi T\}alib. Jakarta: Litera AntarNusa. 2008.

Siradjudin Abbas, I'tiqad Ahlusunnah wa al-jama'ah. Jakarta: Pustaka Tarbiyah, 2004.

Muhammad Abid Al-jabri dan Hasan Hanafi, Hiwar al-Mashriq wa al-Magrib. Beirut: alMuassasah al-'Arabiyah,1990.

Bassam Tibi, Islam and The Culural Acomodation of Social Change. California: University of Caliifornia, 1991.

Rumadi, Renungan Santri. Jakarta: Erlangga, 2002.

Bassam Tibi, The Challenge of Fundamntalism: Political Islam and the New World Disorder. California: University of California. 1998.

Martin E. Marty, "What is Fundamentalism? Theological Perspektive”, dalam Kung \& Moltman (ed), Fundamentalism as a Ecumenical Challenge. London: 1993.

Ali Syu'aibi \& Gills Kibil, Meluruskan Radikalisme Islam, terj: Muhtarom. Yogjakarta: Duta AKsara Mulia, 2010. 